Кубеева Мара Маулитовна, Магистр педагогических наук Карагандинский государственный университет имени Е.А. Букетова

г. Караганда, Казахстан. E-mail: mara0393@mail.ru

ORCID ID 0000-0001-8957-5318

\title{
ФОРМИРОВАНИЕ ПРОФЕССИОНАЛЬНОЙ КОММУНИКАТИВНОЙ КОМПЕТЕНТНОСТИ УЧИТЕЛЕЙ ИНОСТРАННОГО ЯЗЫКА ПОСРЕДСТВОМ ИНФОРМАЦИОННО-КОММУНИКАЦИОННЫХ ТЕХНОЛОГИЙ
}

\begin{abstract}
Аннотация: данная статья посвящена роли информационной образовательной среды 6 формировании профессиональной коммуникативной компетентности учителя иностранного языка. Информачионная образовательная среда представлена интернетом и электронной почтой, большие возможности которых в совершенствовании иноязычных коммуникативных умений студентов языковых специальностей отражены в статье. Рассмотрены позиции исследователей относительно компетентностного подход в обучении, а также анализированы понятия компетенция и компетентность. Большое внимание уделено дидактическому потенциалу информационных технологий, создающих реальные условия для развития и совершенствования профессиональной коммуникативной компетентности, а также обмена опытом специалистов разных профессий в общем, студентов и преподавателей иностранных языков в частности. На основе анализа литературных источников, авторы приходят к выводу о том, что информатизация системы образования предъявляет определенные требования к проиессу формирования профессиональной коммуникативной компетентности будущих специилистов.
\end{abstract}

Ключевые слова: компетентность, профессиональная компетенция, информационная обучающая среда, интернет.

\section{FORMATION OF PROFESSIONAL COMMUNICATIVE COMPETENCE OF FOREIGN LANGUAGE TEACHERS BY MEANS OF INFORMATION AND COMMUNICATION TECHNOLOGIES}

Kubeyeva Mara Maulitovna, Master of Pedagogical Sciences Karaganda State University named after E.A. Buketov Karaganda, Kazakhstan.E-mail: mara0393@mail.ru ORCID ID 0000-0001-8957-5318

Annotation: this article is devoted to the role of the information educational environment in the formation of the professional communicative competence of a foreign language teacher. The informational educational environment is represented by the Internet and e-mail, the great opportunities of which in the improvement of foreign language communicative skills of students of language specialties are reflected in the article. The positions of researchers regarding the competence-based approach to learning are reviewed, and the concepts of competence and competence are analyzed. Much attention is paid to the didactic potential of information technologies, creating real conditions for the development and improvement of professional communicative competence, as well as the exchange of experience of specialists of various professions in general, students and teachers of foreign languages in particular. Based on the analysis of literary sources, the authors come to the conclusion that the informatization of the education system imposes certain requirements on the process of forming the professional communicative competence of future specialists.

Keywords: competence, professional competence, information learning environment, Interne.

Коммуникативная компетенция
Материалы Международной практической интернет-конференции «Актуальные Проблемы Науки» 
В результате инновационных преобразований, происходящих в обществе и в системе образования, особую ценность для улучшения условий жизни, дальнейшего эффективного развития современного человека имеет не только объем знаний, а также навыки и уровень владения ими в той или иной сфере деятельности [1]. Имея определенный уровень общего или профессионального образования, человек, владеет в определенной степени необходимыми ему навыками, позволяющими выполнять работу, но условия современного общества таковы, что если человек хочет,улучшить свой уровень жизни, ему необходим более высокий уровень владения профессиональными навыками для улучшения эффективности результатов работы. Актуальной становится проблема развития компетенций. В 70-х гг. 20 в. Дэвид К.МакКлеланд опубликовал результаты исследований, доказывавшие, что отличное знание учебных предметов и успешное прохождение тестов еще не означало высокого результата работы. Тогда Дэвид К.МакКлеланд выявил характеристики человека, позволяющие ему эффективно выполнять ту или иную деятельность. Компетентностный подход оказался актуален для всех сфер деятельности человека, в том числе и применительно к образованию. Компетентностный подход в образовании - главная составляющая новой парадигмы образования, ориентированной на результат. Об этом и говорит в своих научных трудах И.А. Зимняя [2]. Для рассмотрения процесса развития коммуникативной компетенции педагога необходимо определить содержание понятий: «компетентность», «компетенция», «коммуникация», «коммуникативная компетенция».

С позиции аксиологического подхода, под компетентностью понимается в пер вую очередь личностное (или профессионально значимое) качество, способность и т. д. Деятельностный подход позволяет на первый план вывести такие стороны компет ентности, как совокупность умений, обеспечивающих возможность самореализации л ичности или готовности к осмысленному осуществлению определенного вида деятел ьности. Профессиональная компетентность педагога предполагает наличие у него ум ений педагогически мыслить и педагогически действовать. К умениям педагогически мыслить относятся: аналитические, проектировочные, рефлексивные; к умениям педа гогически действовать: организаторские и коммуникативные. Это значит, что професс иональная компетентность педагога понимается как интегративная характеристика, вк лючающая когнитивный (профессиональные знания), деятельностный (профессиональн ые умения и опыт) и профессионально-личностный компоненты.

Профессиональная деятельность педагога относится к сфере «повышенной реч евой ответственности» [3] и во многом зависит от коммуникативной компетентности , которая рассматривается исследователями как «многоуровневая совокупность когни тивных, эмоциональных и поведенческих особенностей личности, многоуровневое пр офессионально значимое качество его личности, опосредующее его коммуникативную деятельность, направленную на установление, поддержание и развитие контактов с участниками педагогического процесса» [3]

В исследованиях ученых наряду с понятием «компетентность» используется и понятие «компетенция», которое также имеет вариативное описание в различных источниках. Термины «компетентность» и «компетенция» приобретают все более широкое распространение в образовательной среде. Изучение психолого-педагогической литературы (А.Г. Бермус, В.А. Болотов, В.Н. Введенский, И.А. Зимняя, О.Е. Лебедев, Н.В. Кузьмина, Г.К. Селевко, А.В. Хуторской и др.) позволяет сделать вывод о том, что в педагогической практике данные понятия употребляются довольно часто, однако в настоящий момент отсутствует однозначная трактовка понятий «компетенция» и «компетентность». Кроме того, расходятся мнения ученых относительно соотношения

Коммуникативная компетенция
Материалы Международной практической интернет-конференции «Актуальные Проблемы Науки» 
рассматриваемых категорий, их классификаций и структур. В педагогической науке сформировалось два направления - синонимизирующее и дифференцирующее рассматриваемые понятия. Исследователи, относящиеся к первому направлению (В.А. Болотов, В.С. Леднев, М.В. Рыжаков, В.В. Сериков и др.) отождествляют данные понятия, уделяя особое внимание практической направленности компетенций. Представители второго направления (И.А. Зимняя, О.М. Мутовская, А.В. Хуторской, С.Е. Шишов и др.) принципиально разграничивают данные понятия, определяя компетентность как первичную категорию. И.А. Зимняя понимает под компетенцией некоторые внутренние, потенциальные, сокрытые знания, представления, системы ценностей, которые потом проявляются в компетентности человека. А.В. Хуторской рассматривает компетенцию как «социальное требование (норму) к образовательной подготовке ученика, необходимой для его качественной продуктивной деятельности в определенной сфере». Компетентность с его точки зрения - это «владение соответствующей компетенцией, совокупность личностных качеств ученика, обусловленных опытом его деятельности в определенной социально и личностно- значимой сфере» [5].

Коммуникация (от англ. communicate -сообщать, передавать) Вербальная коммуникация - целенаправленный процесс передачи при помощи языка (языкового кода) некоторого мысленного содержания. Ряд авторов считают коммуникативную функцию языка и речи основной и первичной их функцией, а иногда даже утверждается и единственность функции коммуникации. Существует и невербальная коммуникация, которая, с одной стороны, может дублировать и поддерживать вербальную коммуникацию, с др. - обеспечивать нецеленаправленную передачу всякого психического содержания (не только внутренно-вербального, но и образного, эмоционального, мотивационного).[6]

В российской лингводидактике термин «коммуникативная компетенция» был введен в научный обиход М.Н.Вятютневым. Он предложил понимать коммуникативную компетенцию «как выбор и реализацию программ речевого поведения в зависимости от способности человека ориентироваться в той или иной обстановке общения; умение классифицировать ситуации в зависимости от темы, задач, коммуникативных установок, возникающих у учеников до беседы, а также во время беседы в процессе взаимной адаптации». Хотя данное определение является достаточно развернутым, необходимо отметить, что в современной методике преподавания иностранного языка существует достаточно серьезный разброс мнений, что же включает в себя такое ёмкое понятие, как «коммуникативная компетенция». Согласно видному российскому исследователю В.В. Сафоновой данный термин следует рассматривать, как совокупность трёх составляющих: языковой, речевой и социокультурной . Если первые две составляющие не вызывают никаких сомнений, то по поводу социокультурной компетенции в мировом, а также и в российском, научных кругах существует многочисленные разночтения, так как каждый автор вкладывает в него чисто авторское понимание, что никак не способствует объединению усилий в разработке эффективных подходов и методик формирования социокультурной компетенции в единой логике на различных ступенях языкового и профессионально-педагогического образования.

Объем содержания понятия "коммуникативная компетенция" определяется потребностью использовать язык сообразно практическим целям профессиональной деятельности с учетом специфики условий протеканияя коммуникации в профессиональной среде. С одной стороны, речь идет о владении языковыми средствами и знаний правил и норм их функционирования в языке. Иными словами, формирование иноязычной коммуникотивной компетенции без основ закладывания основ

Коммуникативная компетенция
Материалы Международной практической интернет-конференции «Актуальные Проблемы Науки» 
лингвичтической компетенции, что предполагает усвоение лексических и грамматических, а также правил лексической и стилистической сочетаемости [7].

Социокультурная компетенция подразумевает знание национально-культурных особенностей социального и речевого поведения носителей языка (их обычаев, этикета, социальных стереотипов, истории и культуры страны) и способов пользоваться ими в процессе общения. Формирование данной компетенции проводится в контексте диалога культур, способствует достижению межкультурного понимания между людьми и становлению их толерантного отношения к другой культуре. Исходя из вышесказанного, нам представляется возможным более полно раскрыть понятие коммуникативной компетенции. Коммуникативная компетенция педагога - это интегративное качество личности, предусматривающее знания и навыки, необходимые для эффективного социального взаимодействия (при сохранении индивидуальности каждого элемента социума) с целью передачи, взаимообмена информацией, установлением контактов, управления ситуацией с помощью вербальных и невербальных средств. Под интегративным качеством личности (с точки зрения философии) понимается элемент подструктуры личности, обладающий направленностью, способностью к саморазвитию и функционированию. В системе интегративных качеств ведущая роль принадлежит базисным качествам [8]. Интегративные качества связывают личностные качества вокруг направленности личности.

Существенную роль в ориентации на активное обучение иностранному языку в неязыковом вузе играет еще одна особенность профессиональной деятельности рост общения на иностранном языке с помощью информационно-коммуникационных технологий (ИКТ). Взаимопонимание между иноязычными коммуникантами при решении профессиональных задач возможно лишь при наличии профессиональной коммуникативной компетентности. Особое значение в достижении этого качества придается мультимедийным, телекоммуникационным, проектным методам обучения, а также междисциплинарному подходу. Понимание и смысл термина «коммуникативная компетентность» рассматривали А.Б. Зверинцев, А.А. Мурашов, Н.Н. Обозов, И.И. Рыданова, И.А. Стернин, А.В.Сычева и другие специалисты.

Что же такое «информационные технологии»? В современной науке существует много различных подходов к определению термина «информационные технологии». Согласно «Словарю методических терминов» (авторы Э. Г. Азимов, А. Н. Щукин) информационные технологии - это система методов и способов сбора, накопления, хранения, поиска, передачи, обработки и выдачи информации с помощью компьютеров и компьютерных линий связи. Информационными технологиями, как правило, называют технологии, использующие такие технические средства как аудио, видео, компьютер, Интернет. В настоящее время необходимо умение получать информацию из разных источников, пользоваться ей и создавать ее самостоятельно. Широкое использование ИКТ открывает для преподавателя новые возможности в преподавании иностранного языка.[9]

Направления использования ИКТ на уроках иностранного языка для формирования профессиональной коммуникативной компетентности будущих учителей иностранного языка:

Использование информационно-коммуникационных технологий на уроках иностранного языка раскрывает огромные возможности компьютера как эффективного средства обучения. Компьютерные обучающие программы позволяют тренировать различные виды речевой деятельности и сочетать их в разных комбинациях, осознать языковые явления, способствуют формированию лингвистических способностей, создают коммуникативные ситуации, автоматизируют языковые и речевые действия, а также

Коммуникативная компетенция
Материалы Международной практической интернет-конференции «Актуальные Проблемы Науки» 
обеспечивают реализацию индивидуального подхода и интенсификацию самостоятельной работы обучающихся.

Использование программы Power Point для создания презентаций при введения лексического, грамматического, страноведческого материала, делает процесс обучения привлекательным и лёгким для понимания. Также обучающиеся могут создавать компьютерные презентации с целью представления результатов проектной деятельности. При организации этого вида деятельности также преследуется и практическая цель научить обучающихся использовать знания, умения и навыки, полученные на уроках английского языка.

Широкое использование Интернет-ресурсов для развития коммуникативной компетенции, которые дают возможность доступа к богатейшим источникам англоязычной информации. Можно использовать этот ресурс для погружения обучающихся в англоязычную среду во внеурочной деятельности при самостоятельной работе. Для этого подходят следующие ресурсы:

Онлайн версии зарубежных газет. Естественно, для обучающихся чтение и обсуждение последних мировых новостей интереснее и полезнее, чем работа со старыми печатными изданиями. Так как в Интернет новости постоянно обновляются, они всегда свежи и позволяют обучающимся ориентироваться в более широком кругу событий и заголовков. Наиболее часто используемые сайты: http://english.mn.ru/english, http://www.whitehouse.gov, http://www.bbc.co.uk/home/today/index.shtml, http://www.washingtonpost.com, http://cnn.com.

Варианты известных телевизионных викторин Јeopardy (в русской версии “Своя игра"), Weel Of Fortune (русское "Поле Чудес"), Bookworm, Super Text Twist, Word Slinger). · Мультимедийные материалы, представленные Интернет (на языке оригинала можно прослушать и концерт интересующего учащихся исполнителя, и интервью с известным человеком, и трансляцию популярного радиоканала и даже посмотреть новинки кино.

писателей.

On-line версии произведений известных английских и американских

- Словари, справочники, топики по разным темам, on-line тесты и т. п. Вот несколько примеров организации работы с материалами Интернет.

- Если удаётся записать аудиотекст из Интернета, то можно организовать работу с записью. Внедрение в образовательный процесс новых информационных технологий позволило выявить следующие факторы их эффективности:

Интенсификация учебного процесса

- Создание благоприятных возможностей для овладения учебным материалом на основе принципа наглядности, реализующегося благодаря широким возможностям ИКТ- цвет, видео, музыка, графика, рисунки и т. д.

- Усиление мотивации

- $\quad$ Индивидуализация учебного процесса

- $\quad$ Углубленность в усвоении конкретного материала

- $\quad$ Пополнение словарного запаса, как активного, так и пассивного, лексикой современного иностранного языка, отражающего определенный этап развития культуры народа, социального и политического устройства общества, используя аутентичные тексты из страны изучаемого языка;

В заключении нужно подчеркнуть, что внедрение в учебный процесс информационных технологий вовсе не исключает традиционные методы обучения, а гармонично сочетается с ними на всех этапах обучения: ознакомление, тренировка,

Коммуникативная компетенция
Материалы Международной практической интернет-конференции «Актуальные Проблемы Науки» 
применение, контроль. А использование информационных технологий позволяет не только многократно повысить эффективность обучения, но и стимулировать обучающихся к дальнейшему самостоятельному изучению английского языка.[9].

Чтобы применение ИКТ стало средством воспитания личности будущего специалиста и фактором его профессионального развития, необходимо формировать профессиональную коммуникативную компетентность студента, при этом главную роль в решении этой задачи играет преподавание иностранного языка. Однако по-прежнему многие преподаватели не ориентируются на формирование у студентов профессиональной коммуникативной компетентности средствами иностранного языка, видя главную цель в формировании знаний и умений, обозначенных в государственном образовательном стандарте, а информационно-коммуникационные технологии используются в образовательном процессе преимущественно (или только) как средство получения информации и аутентичного языкового материала.

Незначительно используются коммуникативные возможности Интернеттехнологий в организации учебного и научного общения вследствие недостаточного уровня профессиональной коммуникативной компетентности студентов [10].

\section{СПИСОК ЛИТЕРАТУРЫ}

1. Сластенин В. А. Педагогика : учеб пособие для студ. высш. пед. учеб. заведений ; под ред. В. А. Сластенина. М. : Академия, 2002.

2. Зимняя И. А. Ключевые компетенции - новая парадигма результата образования // Высшее образование сегодня. 2003. № 5. С. 34-42.

3. Федоренко Т.Г. Моделирование педагогических ситуаций в процессе развития коммуникативной компетентности будущего учителя начальных классов. Дис. канд. пед. наук. - М., 2005 . - 207 с.

4. 4.Риторика: учеб. / З.С. Смелкова, Н.А. Ипполитова, Т.А. Ладыженская; под р ед. Н.А. Ипполитовой. - М.: ТК Велби, Издательство Проспект, 2006. 448 c.

5. Хуторской, 2007: 110

6. Кобзева Н. А. Коммуникативная компетенция как базисная категория современной теории и практики обучения иностранному языку // Молодой ученый. — 2011. №3. Т.2. - С. 118-121.

7. Шашкова В.Н. Формирование профессиональной коммуникативной компетенции иностранных слушателей средствами английского языка языку // Научнометодический электронный журнал "Концепт". — 2018. — №3. V2. — 0,4 п.л. —//еconcept.ru/2018/186015.htm.

8. Мещеряков Б., Зинченко В. Большой психологический словарь

9. Нигай Л. С. Использование ИКТ для формирования коммуникативной компетентности на уроках английского языка [Текст] // Педагогическое мастерство: материалы III Междунар. науч. конф. (г. Москва, июнь 2013 г.). — М.: Буки-Веди, 2013. - С. 117-119.

10. Информационно-коммуникационные технологии как средство формирования профессиональной коммуникативной компетентности студентов экономических специальностейтема диссертации и автореферата по ВАК 13.00.08, кандидат педагогических наук Васичкина, Ольга Николаевна.

Коммуникативная компетенция
Материалы Международной практической интернет-конференции «Актуальные Проблемы Науки» 